\title{
Effect of Inhibitors on the Corrosion of Zinc in Dry-Cell Electrolytes
}

\section{By Clarence K. Morehouse, ${ }^{1}$ Walter J. Hamer, and George W. Vinal}

\begin{abstract}
This paper deals with a study of substitutes for mercury and chromate films in curtailing the corrosion of the zinc anode of Leclanché dry cells at high temperatures. Organic compounds containing the carbonyl group (such as furfural), heterocyclic nitrogen-containing compounds like quinaldine, and certain commercial products were found to be effective in retarding the corrosion of zine in dry-cell electrolytes.

Although these types of materials retarded the corrosion of zinc, dry cells made with them did not have the expected increase in shelf-life or electrical output. The inhibitors either reacted with the paste wall to decrease its strength, or formed an insoluble film over the entire surface of the zinc anode that contributed to its internal resistance. No parallelism was observed between the electrical output of the cells and the percentage of inhibitor used in their construction. On the other hand, the paste wall of the dry cell, which is usually a starch-flour gel, was found to have inhibiting properties. Starch was inert, but flour had inhibiting properties. The active inhibiting agent of the flour is gluten. The constituents of gluten, namely, glutenin, and gliadin and mesonin in different states of aggregation were isolated, and the last two were found to be effective in retarding the corrosion of zinc. These materials can be incorporated in dry cells and increase their capacity at moderate temperatures.
\end{abstract}

\section{Introduction}

When the Leclanché type of dry cell is subjected to high-temperature storage, one of the sources of failure is the increased rate of corrosion of the zinc anode [1]. ${ }^{2}$ The zinc anode also corrodes at normal temperatures $\left(18^{\circ}\right.$ to $\left.30^{\circ} \mathrm{C}\right)$, and it is common practice either to amalgamate the zinc or to use chromate films to curtail local action. At high temperature neither of these methods is so effective as to yield good shelf life. In this paper alternate methods are described, including the use of inhibitors and modifications of the paste wall to increase its inhibiting properties.

The theory of corrosion inhibitors is still in the formative stage, and their choice is largely a matter of trial and error. However, the principles postulated for the corrosion of steel may be considered. In the dry cell the reactions are of two types: (1) the cell discharge reaction, which gives the avail-

\footnotetext{
1 Now with Olin Industries, Western Cartridge Co., East Alton, Ill.

2 Figures in brackets indicate the literature references at the end of this paper.
}

able electrical energy, and (2) the corrosion reaction (local action), which is a side reaction, and from which no electric energy is available. These two reactions may be formulated as follows:

1. The dry-cell reaction $[2,3]$ in which no $\mathrm{H}_{2}$ gas is formed:

$$
\mathrm{Zn}+2 \mathrm{MnO}_{2}=\mathrm{ZnO} \cdot \mathrm{Mn}_{2} \mathrm{O}_{3} \text {. }
$$

2. Corrosion reaction in which $\mathrm{H}_{2}$ gas is formed:

Reaction at anodic areas: $\mathrm{Zn} \rightleftharpoons \mathrm{Zn}^{++}+2 \epsilon$,

Reaction at cathodic areas:

$$
\mathrm{Zn}^{++}+2 \mathrm{NH}_{4} \mathrm{Cl}+2 \epsilon \rightleftharpoons \mathrm{Zn}\left(\mathrm{NH}_{3}\right)_{2} \mathrm{Cl}_{2}+\mathrm{H}_{2},
$$

Over-all corrosion reaction:

$$
\mathrm{Zn}+2 \mathrm{NH}_{4} \mathrm{Cl} \rightarrow \mathrm{Zn}\left(\mathrm{NH}_{3}\right)_{2} \mathrm{Cl}_{2}+\mathrm{H}_{2} .
$$

The corrosion reaction may also be considered more simply as the discharge of hydrogen ions that penetrate to the cathodic areas of the zinc can. The corrosion and the cell-discharge reactions are not the same, and it should be possible to retard the 
corrosion reaction without materially affecting the discharge reaction. In order to accomplish this, the cathodic areas of the zinc must be made more anodic, or the anodic areas must be rendered ineffective until current is drawn from the cell. Amalgamation of the zinc and chromate films function in this sense.

In the steel industry, organic substances are added to the acid pickling bath to inhibit the corrosion of the metallic iron. The theory of these inhibitors is that they form an ionizable salt with the acid, whereby positive inhibitor ions are formed that are attracted by electrical forces to the cathodic areas. They are not discharged but replace the iron ions in a Helmholtz double layer, and when a state of equilibrium is attained they form a protective layer over the metallic surface. The effectiveness of this layer depends on its ability to prevent hydrogen ions from penetrating to the cathodic areas where they are discharged. The size, nature, position on the metallic surface, and the closeness of packing of the inhibitor ions will determine the effectiveness of this protective layer.

These types of inhibitors are classified as cathodic inhibitors. Attention was given to this type, because in the dry cell it is desirable that the corrosion of the zinc be inhibited by stopping the corresponding cathodic reaction and not the anodic one, which is necessary for the production of electrical energy by the cell. An anodic inhibitor, unless used in adjusted amounts, would not be desirable in that it would not only stop the cell-discharge reaction but might lead to localized corrosion and cause perforation of the zinc can. Chromates act as anodic inhibitors, and experience with chromate films indicates that they either become ineffective when current is drawn from the cell, or that the chromates function differently in the presence of the paste wall (starch-flour gels).

In many corrosion problems it is possible to reduce and sometimes eliminate the corrosion by altering the existing environments. With dry cells, however, the environments are necessary from the standpoint of electrical output and little changes can be made in them. The electrolyte in the usual type of dry cell consists of aqueous solutions of ammonium and zinc chlorides. There is an abundance of chloride ions, which are small in ionic volume, very mobile, and highly penetrating. Dry cells have been made with electrolytes composed of salts of anions other than chloride but with little success. Chlorides are necessary from the standpoint of electrical output, because they prevent the anode from becoming passive when the cell is discharged. Therefore, studies were confined to concentrated aqueous solutions of ammonium chloride with or without additions of zinc chloride. The corrosion rate of the zinc anode may be altered somewhat, but not significantly, by changing the concentration of the chloride or by using zinc containing various percentages of other metals. In this work, commercial zinc containing 0.25 to 0.60 percent of cadmium, 0.20 to 0.60 percent of lead, and less than 0.03 percent of iron was used.

\section{Experimental Procedure}

The rate of corrosion of the zinc was determined by a method suggested and used by D. N. Craig, in which the amount of hydrogen that is evolved under controlled conditions is measured. The apparatus consisted of an inverted test tube closed by a rubber stopper through which passed a capillary tube (fig. 1). Within the test tube the sample of zinc and electrolyte were placed, the electrolyte completely filling the test tube and capillary tube. In the inverted position, the gas liberated at the zinc rises in the tube and expels an equal volume of electrolyte through the capillary tube. The tube was weighed from day to day, and the volume of gas evolved was calculated from the change in weight and the known density of the solutions. Measurements were made at $54^{\circ} \mathrm{C}$, a temperature reached in storage in the tropics during the past war. In some experiments ther ate of corrosion was determined by a loss-in-weight method, considered later.

\section{Results}

Data given in tables 1 and 2 show the effects of amalgamation and of chromate films on the rate of corrosion of zinc in ammonium chloride maintained at $54^{\circ} \mathrm{C}$. AA-size zinc cans $(17 / 32$ in. in diameter and $17 \%$ in. in height) were used. Neither amalgamation of the zinc nor use of chromate films was as effective as desired at $54^{\circ} \mathrm{C}$. Any excess of mercury decreases the mechanical strength of the cans. 

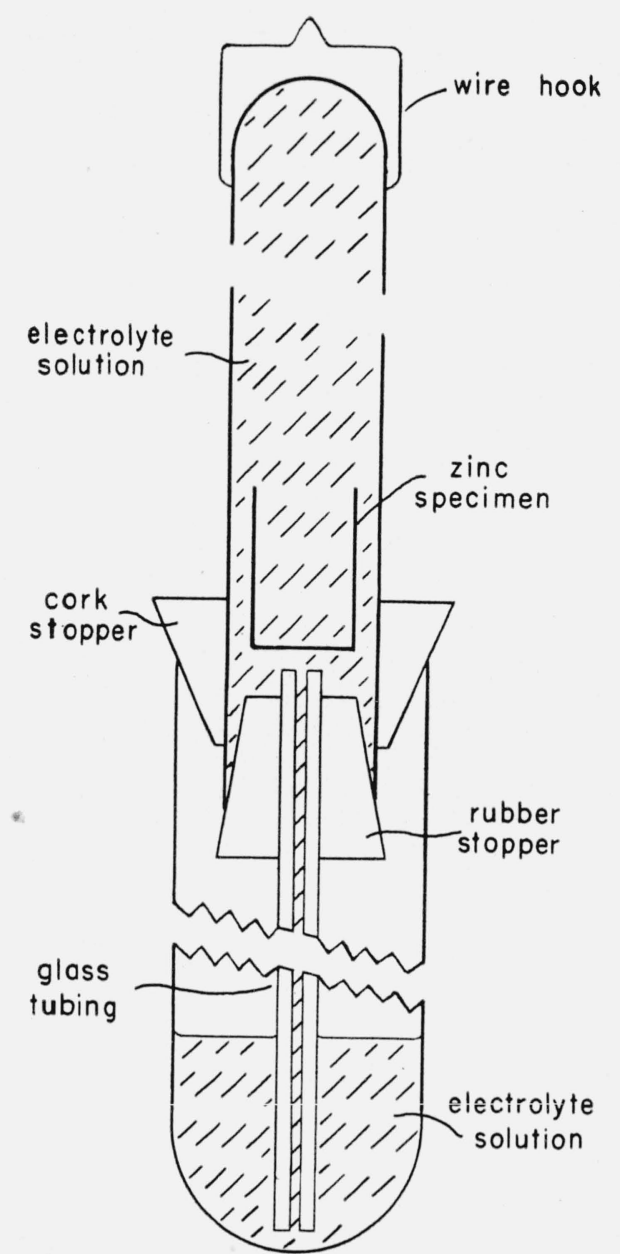

Figure 1. Gas tube for measuring the rate of corrosion of zinc cans.
TABLE 1. Effect of amalgamation on the corrosion of zinc electrodes at $54^{\circ} \mathrm{C}$

[AA-size zinc cans totally immersed in $20 \% \mathrm{NH}_{4} \mathrm{Cl}$ solutions]

\begin{tabular}{|c|c|c|}
\hline \multirow{2}{*}{$\mathrm{HgCl}_{2}$ per AA-size zinc can } & \multicolumn{2}{|c|}{$\begin{array}{l}\text { Hydrogen evolved at } \\
54^{\circ} \mathrm{C} \text { for- }\end{array}$} \\
\hline & 1 day & 2 days \\
\hline$g$ & $m l$ & $m l$ \\
\hline $0.00 \ldots$ & 8.1 & 15.6 \\
\hline . $01 \ldots$ & 4. 8 & 11.1 \\
\hline $.02 \ldots$ & 4. 6 & 14.4 \\
\hline $.04 \ldots \ldots$ & 3.1 & 9.1 \\
\hline . 08 & 1.9 & 8.7 \\
\hline $.10 \ldots$ & 1.9 & 7. 2 \\
\hline $.15 \ldots$ & 1.8 & 6.3 \\
\hline $.20 \ldots$ & 1.7 & 7. 2 \\
\hline
\end{tabular}

The inhibiting properties of a large number of materials were studied. They may be classed as commercial or industrial by-products, organic compounds, inorganic compounds, and colloidal materials. The organic compounds may be subdivided into noncyclic and heterocyclic nitrogen-, oxygen-, or sulfur-containing compounds. Isocyclic compounds would not be expected to be effective inhibitors because of their symmetry. The one tried, salicyl aldoxime, was not effective, as anticipated.

Results obtained with D-size zinc cans (1 1/4 in. in diameter and $2 \frac{1}{4}$ in. in height) immersed at $54^{\circ} \mathrm{C}$ in saturated aqueous solutions of ammonium chloride to which certain commercial products or organic compounds were added are given in tables 3 and 4 . The data were extensive,

TABLE 2. Effect of chromate films and dichromates on the corrosion of zinc electrodes at $54^{\circ} \mathrm{C}$

[AA-size zine cans totally immersed in saturated $\mathrm{NH}_{4} \mathrm{Cl}$ solutions]

\begin{tabular}{|c|c|c|c|c|c|c|c|c|c|}
\hline \multirow{2}{*}{ Inhibitor } & \multicolumn{9}{|c|}{ Hydrogen evolved at $54^{\circ} \mathrm{C}$ for- } \\
\hline & 1 day & 5 days & 10 days & 15 days & 20 days & 25 days & 30 days & 35 days & 40 days \\
\hline Control (no film).. & $\begin{array}{l}m l \\
\quad 3.3\end{array}$ & $\stackrel{m l}{>13}$ & $\begin{array}{c}m l \\
(1)\end{array}$ & $m l$ & $m l$ & $m l$ & $m l$ & $m l$ & $m l$ \\
\hline 10-second Cronak treatment ${ }^{2} \ldots$. & 0.5 & 3.5 & 6.1 & 12.1 & $>13$ & (1) & & & \\
\hline 10-minute Cronak treatment ${ }^{2}$ & .7 & 3.5 & 5.4 & 6.8 & 6.7 & 7.9 & 8.3 & 9.3 & $>13$ \\
\hline $0.5 \% \mathrm{~K}_{2} \mathrm{Cr}_{2} \mathrm{O}_{7}$ added to solution & 3.4 & 6.7 & 9.3 & 10. 9 & 12.2 & $>13$ & (1) & & \\
\hline $1.0 \% \mathrm{~K}_{2} \mathrm{Cr}_{2} \mathrm{O}_{7}$ added to solution & 2.7 & 6.4 & 8.9 & 10.9 & 12.2 & $>13$ & (1) & & \\
\hline $2.0 \% \mathrm{~K}_{2} \mathrm{Cr}_{2} \mathrm{O}_{7}$ added to solution $\ldots \ldots \ldots$ & 3.9 & 8.1 & 10.5 & .... & ........... & $>13$ & (1) & 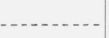 & $\cdots$ \\
\hline
\end{tabular}

1 Experiment was discontinued.

${ }^{2}$ The Cronak process, developed by the New Jersey Zinc Co., involves the treatment of the zinc with a solution containing sodium dichromate and sulfuric acid. 
TABLE 3. Effect of certain commercial inhibitors on the corrosion of zinc electrodes at $54^{\circ} \mathrm{C}$

(D-size zinc cans immersed in saturated solutions of ammonium chloride to which 1 percent of inhibitor was added)

\begin{tabular}{|c|c|c|}
\hline Inhibitor & $\begin{array}{l}\text { Duration } \\
\text { of test }\end{array}$ & $\begin{array}{l}\text { Rate of } \\
\text { corrosion }\end{array}$ \\
\hline & Days & $m l \mathrm{H}_{2} / d a y$ \\
\hline (n) & 1 & 3. 5 \\
\hline Zinc dibutyl-dithiocarbamate & 1 & 5. 7 \\
\hline $\begin{array}{l}\text { Piperdino pentamethylene dithio- } \\
\text { carbamate }\end{array}$ & 1 & 5.0 \\
\hline 2-Mercaptobenzothiazole............ & 1 & 4. 3 \\
\hline Tetramethyl thiuram disulfide...... & 5 & 1. 7 \\
\hline Commercial oils 1 & 1 to 20 & 1.3 to 0.5 \\
\hline $\begin{array}{l}\text { Proprietary compounds of unknown } \\
\text { composition }{ }^{2}\end{array}$ & 1 to 160 & 10.4 to 0.023 \\
\hline
\end{tabular}

1 Three types.

${ }_{2}$ Eighteen types; most of these were believed to be heterocyclic organic compounds of the mercapto type.

and consequently only an average corrosion rate is listed for each material. This rate was obtained by dividing the total volume of gas evolved by the time (in days) of the test. The rates varied somewhat with the time, as shown in figure 2 , for the better inhibitors. However, a preliminary choice of inhibitors and a comparison of their effective- ness may be made from the average rates. One percent of inhibitor was used in most cases. Lesser amounts were generally ineffective and larger amounts, as will be shown later, were undesirable in dry cells.

Of the commercial inhibitors, only tetramethyl thiuram disulfide, the commercial oils, and certain of the proprietary compounds of unknown composition were more or less effective. As the composition of these materials was unknown, no general principle for making a choice of possible inhibitors could be deduced from their study. Consequently, known organic and inorganic compounds were studied next.

The results obtained with organic compounds show that noncyclic compounds have little or no inhibiting action with the exception of crotonaldehyde. In fact most of these materials were corrosive. Crotonaldehyde exhibits resonance, has conjugated double bonds, and contains the carbonyl group $(=\mathrm{C}=\mathrm{O})$. Mann [4] has shown that the carbonyl group is effective in preventing corrosion of steel. He explained this by the formation of oxonium compounds, which ionize to give a positively charged ion as follows:
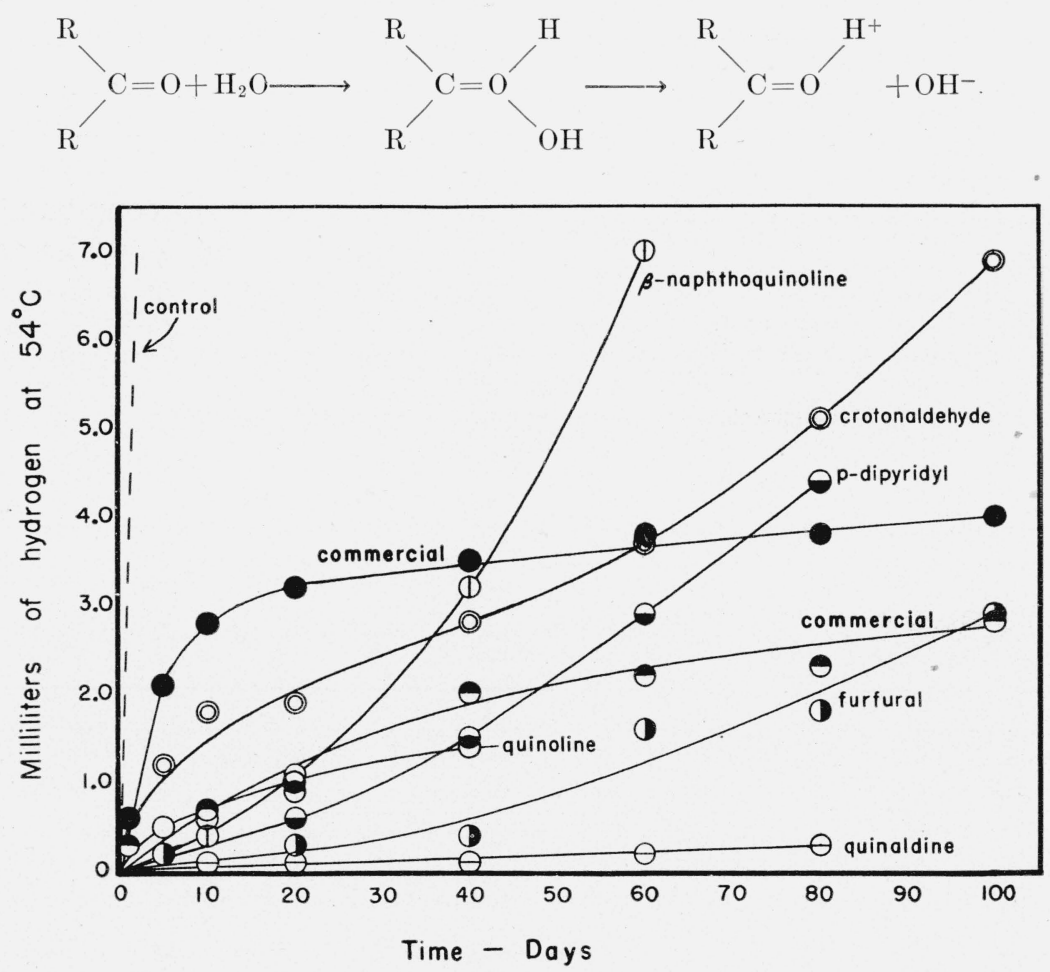

FIGURE 2. Inhibiting action of some materials as a function of time, on the corrosion of zinc in saturated solution of ammonium chloride at $54^{\circ} \mathrm{C}$. 
<smiles>O=Cc1ccoc1</smiles>

furfural

(good)<smiles></smiles>

furyl alcohol

(poor)<smiles>CC=CC=O</smiles>

crotonaldehyde

(good)<smiles>O=C(c1ccco1)C1OCC2CC1C2</smiles>

furil

(poor)<smiles>c1ccccc1</smiles>

\section{hydrofuramide}<smiles>OC(C1CC=CO1)C(O)C1OCC2CC1C2</smiles>

furoin

(fair)

\section{(good)}

Figure 3. Comparison of inhibiting action of compounds with and without the carbonyl group $(=\mathrm{C}=\mathrm{O})$ on the corrosion of zinc in saturated solutions of ammonium chloride at $54^{\circ} \mathrm{C}$.

TABLE 4. Effect of organic compounds on the corrosion of zinc electrodes at $54^{\circ} \mathrm{C}$

(D-size zinc cans immersed in saturated $\mathrm{NH}_{4} \mathrm{Cl}$ solutions to which 1 percent of inhibitor was added unless otherwise indicated)

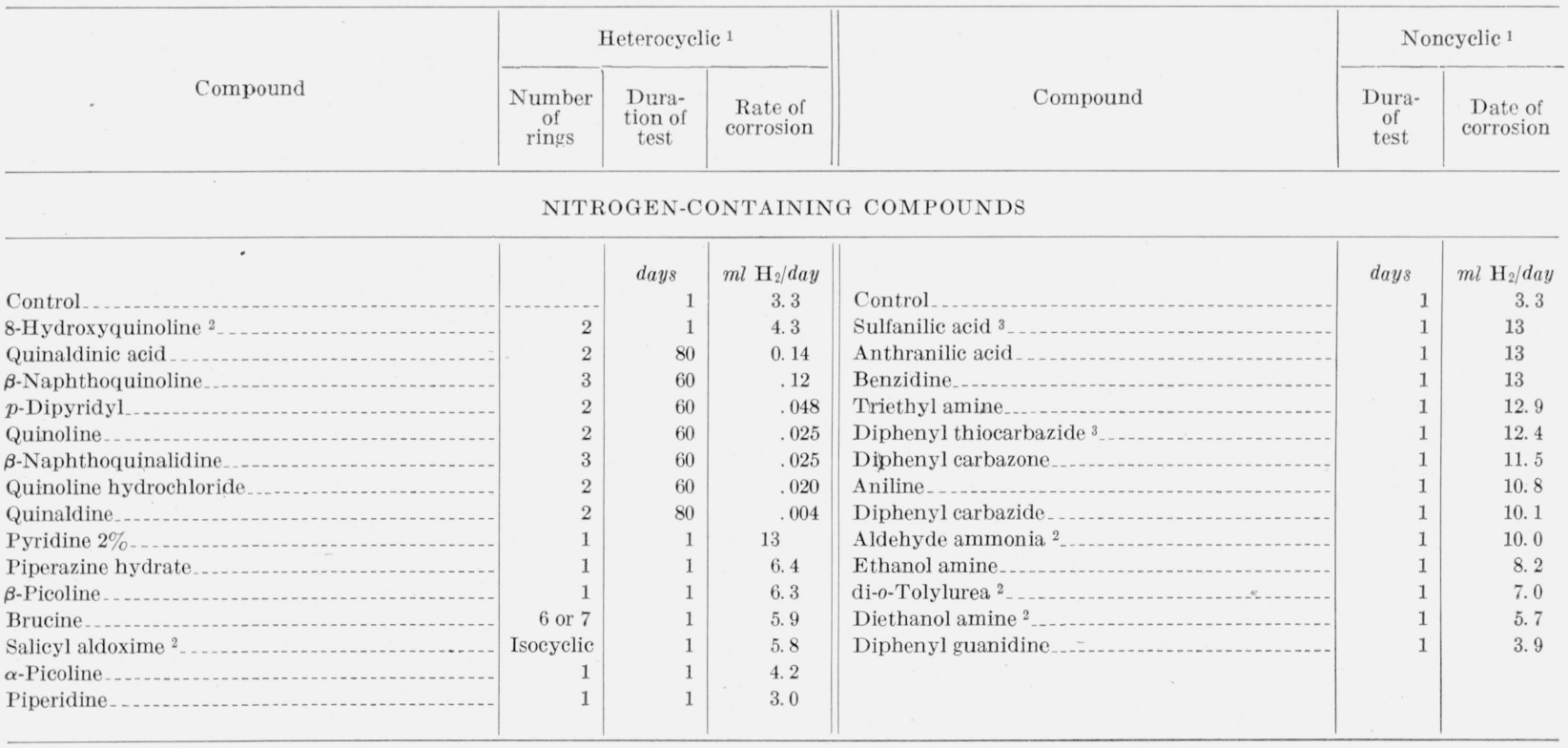

1 Refers to the nitrogen, oxygen, or sulfur in the ring.

2 Also contains oxygen.

3 Also contains sulfur. 
TABLE 4. Effect of organic compounds on the corrosion of zinc electrodes at $54^{\circ} \mathrm{C}$-Continued

\begin{tabular}{|c|c|c|c|c|c|c|}
\hline \multirow[b]{2}{*}{ Compound } & \multicolumn{3}{|c|}{ Heterocyclic ${ }^{1}$} & \multirow[b]{2}{*}{ Compound } & \multicolumn{2}{|c|}{ Noncyclic ${ }^{1}$} \\
\hline & $\begin{array}{c}\text { Number } \\
\text { of } \\
\text { rings }\end{array}$ & $\begin{array}{l}\text { Dura- } \\
\text { tion of } \\
\text { test }\end{array}$ & $\begin{array}{l}\text { Rate of } \\
\text { corrosion }\end{array}$ & & $\begin{array}{c}\text { Dura- } \\
\text { of } \\
\text { test }\end{array}$ & $\begin{array}{l}\text { Date of } \\
\text { corrosion }\end{array}$ \\
\hline
\end{tabular}

OXYGEN-CONTAINING COMPOUNDS

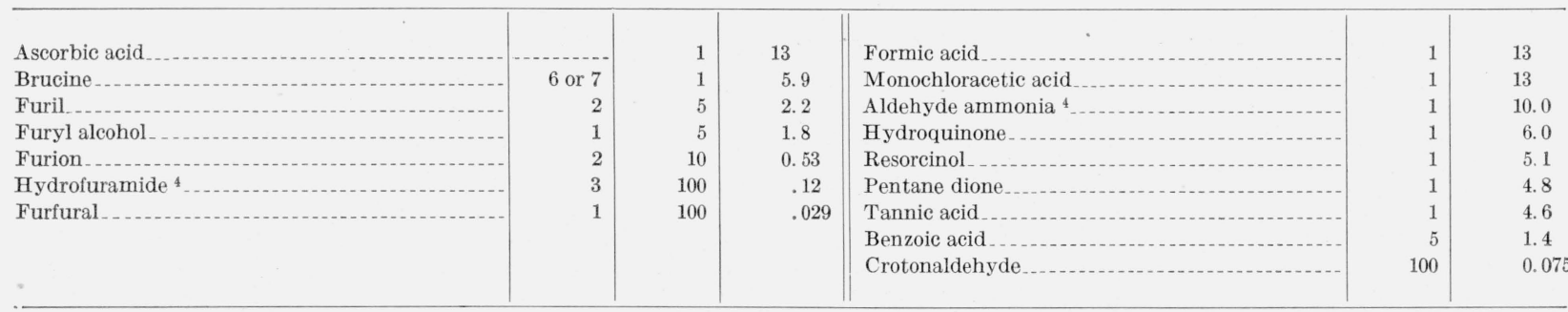

SULFUR-CONTAINING COMPOUNDS (ALL NONCYCLIC)

\begin{tabular}{|c|c|c|c|c|c|c|}
\hline Thiophenol_. & 0 & 1 & 13 & Sulfonated castor oil & 1 & 3.8 \\
\hline Sulfanilic acid & 0 & 1 & 13 & Potassium ethyl xanthate & 5 & 2.0 \\
\hline Diphenyl thiocarbazide & 0 & 1 & 12.4 & Ammonium sulfate (inorganic) & 5 & 2.8 \\
\hline
\end{tabular}

${ }^{4}$ Also contains nitrogen.

The positive ion is attracted to the cathodic areas of the steel and held there in a Helmholtz double layer, thereby increasing the hydrogen overvoltage of the cathodic areas.

The effect of the carbonyl group in retarding the corrosion of zinc is clearly shown for heterocyclic compounds in figure 3. Furfural contains the carbonyl group and is a good inhibitor. When the carbonyl group is converted to an alcoholic group by the addition of strong alkali, a compound, furyl alcohol, is obtained that has no inhibiting properties. It might be expected that furil would be an excellent inhibitor, as it contains two carbonyl groups. However, this is not the case, apparently because the carbonyl groups are effectively shielded from the zinc surface by the furan groups, or close packing of the positively charged ion on the zinc surface is not possible. The ineffectiveness of diphenyl carbazide, diphenyl thiocarbazide, or di-o-tolylurea as inhibitors may be explained on the same basis. The carbonyl or sulfonyl group in these compounds is shielded from the zine surface by the phenyl or toluyl groups. Furoin inhibits slightly the corrosion of zinc, and therefore the carbonyl group in this compound must be attracted to the zinc surface. Hydrofuramide, which contains three furan groups, probably owes its inhibiting properties to the nitrogen and acts as a positively charged amine ion.
Heterocyclic compounds were the most effective inhibitors, providing a second or third ring was attached to the heterocyclic group. This is shown in figure 4. Pyridine, piperidine, $\alpha$-picoline, and $\beta$-picoline, which are simple heterocyclic compounds containing nitrogen in the ring, had little or no inhibiting action, although these compounds may form addition compounds with acids or water and subsequently ionize to positively charged ions. On the other hand, phenyl and naphthalene derivatives, such as quinoline, $p$-dipyridyl, quinaldine, $\beta$-naphthoquinoline, and $\beta$-naphthoquinaldine do show inhibiting action. Here the positively charged ion is attracted to the cathodic areas at the nitrogen, and the large molecule, being unsymmetrical, is inclined at an angle to the zinc surface whereby a large area of the zinc surface is effectively covered. $p$-Dipyridyl is attracted to the zinc at both nitrogens and probably lies flat on the surface of the zinc and is therefore a good inhibitor. These conclusions agree, in the main, with those of Mann [4]. The better proprietary materials probably were heterocyclic compounds. The compound, 8-hydroxyquinoline shows no inhibiting properties, as the $\mathrm{OH}^{-}$group favors orientation of the water molecule in its vicinity. This effect probably influences the position of the inhibitor ion in the Helmholtz double layer. 
<smiles>C1CCNCC1</smiles>

Pyridine

(poor)<smiles>C1CCNCC1</smiles>

Piperidine (poor)<smiles>C1CCC2[NH2+]CCCC2C1</smiles>

Quinoline (good)<smiles>C1C[NH2+]C2CCC[NH2+]C2C1</smiles>

p-dipyridyl

(good)<smiles>[CH+]1CCC2C(CCC3CCCCCC32)N1</smiles>

$\beta$-naphthoquinoline (good)<smiles>C[C@H]1CCCCN1</smiles>

$\alpha$-picoline (poor)<smiles>CC1CCCNC1</smiles>

$\beta$-picoline

(poor)<smiles>CCC1CCCCC1[N]C</smiles>

Quinaldine

(good)<smiles>CCC1C([NH2+]C)CCC2CCCCC21</smiles>

$\beta$-naphthoquinaldine

(good)<smiles>[CH2-][C@@H]1C(O)CCCC1CCC[NH2+]</smiles>

8-hydroxy quinoline

(poor)

FIGURE 4. Comparison of heterocyclic-nitrogen containing compounds showing the effect of molecular size on inhibition of corrosion of zinc in saturated solutions of ammonium chloride at $54^{\circ} \mathrm{C}$.

\section{Electrical Characteristics of Dry Cells Containing Inhibitors}

In the foregoing it was shown that a number of organic compounds effectively curtail the local corrosion of zine in saturated solutions of ammonium chloride. A few principles were outlined for making a choice of possible inhibitors. To determine whether these inhibitors could be successfully incorporated in dry cells, a number of D-size cells were made in the usual manner in which some of the better inhibitors were incorporated. The inhibitors were introduced into the cells in one of three ways: (1) by spinning an alcoholic solution of the inhibitor on the zinc can and removing the alcohol by evaporation, (2) by adding the inhibitor, if soluble, to the electrolyte of the paste wall, or (3) by grinding the inhibitor with the cereal (starch and flour) before the paste wall was gelatinized.

On the whole, dry cells made with inhibitors did not give the expected increase in shelf life or electrical output. The inhibitors either reacted with the paste wall and decreased its strength [5], or formed a high-resistant film on the zinc. In the latter case, these compounds probably form an insoluble precipitate over the entire surface of the zinc, which stifles not only the undesirable corrosion reaction, but also the cell-discharge reaction. In fact, Bartram and Kent [6] have shown that zinc and quinaldinic acid react to form an insoluble complex precipitate. Similar complex precipitates may be formed between the zinc and the other organic compounds.

In tables 5 and 6 , the results of "light industrial tests" of the cells are given. The "light industrial test" gives the time in minutes of discharge to a cut-off voltage of 0.90 volt through a resistance of $4 \mathrm{ohms}$ for 4-minute periods beginning at hourly intervals of 8 consecutive hours every day, with 16 -hour rest periods intervening. At $21^{\circ} \mathrm{C}$, the electrical output of cells made with or without inhibitors is approximately the same after 1 week of storage. At high temperatures, however, the cells containing the inhibitors gave less output, probably for the reasons cited above. 
TABLE 5. Light industrial tests of D-size dry cells containing inorganic or commercial inhibitors

\begin{tabular}{|c|c|c|c|c|}
\hline \multirow{3}{*}{ Inhibitor * } & \multicolumn{4}{|c|}{ Discharge after storage at- } \\
\hline & \multirow{2}{*}{$\begin{array}{l}21^{\circ} \mathrm{C} \text {, } \\
1 \text { week }\end{array}$} & \multicolumn{3}{|c|}{$54^{\circ} \mathrm{C}$} \\
\hline & & 1 month & 2 months & 3 months \\
\hline & $\min$ & $\min$ & $\min$ & $\min$ \\
\hline Control at $21^{\circ} \mathrm{C}, 0 \%$ & 788 & 1783 & 1781 & 1778 \\
\hline Control at $54^{\circ} \mathrm{C}, 0 \% \ldots$ & ${ }^{2} 788$ & 779 & 739 & 700 \\
\hline $\mathrm{NH}_{4} \mathrm{HF}_{2}, 1.0 \%$ & 776 & 3 & . & $\ldots$ \\
\hline $\mathrm{K}_{2} \mathrm{Cr}_{2} \mathrm{O}_{7}, 2.0 \%$ & 779 & 699 & 3 & .... \\
\hline Cronak treatment, 5 sec.......... & & 708 & 614 & 192 \\
\hline Cronak treatment, $10 \mathrm{sec}$ & . & 694 & 640 & ${ }^{3} 240$ \\
\hline Cronak treatment, $20 \mathrm{sec}$ & .... & 706 & 650 & ${ }^{4} 280$ \\
\hline Cronak treatment, $40 \mathrm{sec}_{\ldots} \ldots \ldots$. & -- & 681 & 637 & 384 \\
\hline Cronak treatment, $80 \mathrm{sec}_{-}$ & 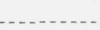 & 689 & 733 & 262 \\
\hline Cronak treatment, $180 \mathrm{sec} \ldots \ldots$ & & 718 & 708 & 288 \\
\hline $\begin{array}{l}\text { Zinc dibutyl - dithiocarbamate, } \\
5.0 \%\end{array}$ & & 676 & 556 & \\
\hline Commercial oils, $5.0 \%$ & . & 622 & 488 & ${ }^{5} 363$ \\
\hline $\begin{array}{l}\text { Proprietary compounds of un- } \\
\text { known composition, } 1 \text { to } 10 \%{ }^{6} \text { - }\end{array}$ & 754 & 544 & 207 & 49 \\
\hline
\end{tabular}

* Inhibitor was mixed with the electrolyte of the paste wall or ground with the cereal. The electrolyte consisted of $22.78 \mathrm{~g} \mathrm{NH}_{4} \mathrm{Cl}, 6.1 \mathrm{~g} \mathrm{ZnC} \mathrm{l}_{2}$, and 49.4 $\mathrm{ml}$ of $\mathrm{H}_{2} \mathrm{O}$. To this was added $7.15 \mathrm{~g}$ each of waxy cornstarch, Buffalo cornstarch, and Pillsbury XXXX wheat flour.

${ }_{1}$ Stored at $21^{\circ} \mathrm{C}$. $\quad 2$ Stored at $54^{\circ} \mathrm{C}$.

3192 minutes at the end of 4 months.

${ }^{4} 133$ minutes at the end of 4 months.

5105 minutes at the end of 4 months.

${ }^{6}$ A verage of 20 tests on different inhibitors.

TABLE 6. Light industrial tests of D-size cells containing organic inhibitors

\begin{tabular}{|c|c|c|c|c|}
\hline \multirow{3}{*}{ Inhibitor 1} & \multicolumn{4}{|c|}{ Discharge after storage at- } \\
\hline & \multirow{2}{*}{$\begin{array}{l}21^{\circ} \mathrm{C} \\
1 \text { week }\end{array}$} & \multicolumn{3}{|c|}{$54^{\circ} \mathrm{C}$} \\
\hline & & 1 month & 2 months & 3 months \\
\hline & $\min$ & $\min$ & $\min$ & $\min$ \\
\hline Control at $21^{\circ} \mathrm{C}, 0.0 \%$ - & 788 & ${ }^{2} 783$ & 2781 & ${ }^{2} 778$ \\
\hline Control at $54^{\circ} \mathrm{C}, 0.0 \%$ - & 3788 & 779 & 739 & 700 \\
\hline Furfural, $0.5 \%$ & 802 & 644 & 368 & 34 \\
\hline Furfural, $1.0 \%$ & 879 & 569 & $<3$ & $\ldots$ \\
\hline Hydrofuramide, $0.5 \%$-- & 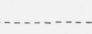 & 524 & 411 & 257 \\
\hline Crotonaldehyde, $1.0 \%$ & $\ldots$ & 464 & $<3$ & \\
\hline Quinaldine, $1.0 \%$ & 731 & 648 & & \\
\hline Quinaldine, $2.0 \%$ & 871 & 664 & 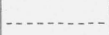 & - \\
\hline Quinaldine. $\mathrm{HCl}, 1.0 \%$ - & 731 & 648 & $<3$ & \\
\hline Quinaldine. $\mathrm{HCl}, 10.0 \%$ & 382 & $<3$ & & \\
\hline Fatty acids of corn, 0.02 & 429 & & & \\
\hline Hydroquinone, $0.03 \%$-- & & $<3$ & 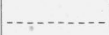 & 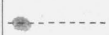 \\
\hline
\end{tabular}

${ }^{1}$ The composition of the paste wall was the same as given in the footnote of table 5. The inhibitor was added to the electrolyte of the paste wall or was ground with the cereal.

${ }^{2}$ Stored at $21^{\circ} \mathrm{C}$. $\quad{ }^{3}$ Stored at $54^{\circ} \mathrm{C}$.

The amount of inhibitor to use in dry cells remains a moot question. Data obtained with the proprietary compounds and with Cronak treatments for various times did not show any correlation between electrical output and percentage of inhibitor. It is probable that there is an optimum concentration for each inhibitor. However, considerable work would be required to ascertain this optimum concentration, which may depend on the concentration of the electrolyte and the composition of the paste wall, because the inhibitors may react with the paste wall.

\section{Inhibiting Characteristics of the Paste Wall}

As the organic and other types of inhibitors for zinc did not improve the shelf life or electrical output of dry cells, studies were made of the organic substances commonly used in the paste wall (or separator) of the dry cell. It has been recognized that starch and flour not only provide a satisfactory separator for the dry cell, but also inhibit to some extent the local corrosion of the zinc electrode, without affecting the electrical output of the dry cell. These materials may be classed as water dispersible organic colloids. Most colloidal particles are positively charged in acid solutions and negatively charged in alkaline solutions. These positively charged particles in acid may then migrate to the cathodically active spots, which are thereby screened or poisoned.

In table 7 are given results obtained at $25^{\circ} \mathrm{C}$ with zinc immersed in saturated aqueous solutions of ammonium chloride to which colloidal materials were added. The natural starches had little protective value. The only modified starch that appears to have appreciable inhibiting properties was a modified starch prepared by H. S. Isbell of this Bureau. His method involved a treatment of starch with chlorine dioxide, whereby the aldehyde end groups of the starch are converted to aldehyde groups.

Cornmeal, zein, and starch glycerite all appear to have inhibiting properties. On the other hand, dextrose and the soluble starches, inulin and glycogen, accelerate the corrosion of zinc in saturated solutions of ammonium chloride. The starches apparently have no protective value, because they are not positively charged. In separating the amylose and amylopectin components of starch by the electrodialytic method, amylose migrates to the anode, and amylopectin remains stationary. Amylose is therefore negatively 
charged and should be without effect on the corrosion of zinc. The high corrosive effect of amylose may be attributed to the butanol that is used to keep it in a soluble condition.

TABLE 7. Results obtained with colloidal materials at $25^{\circ} \mathrm{C}$

[A A-size zinc cans immersed in saturated $\mathrm{NH}_{4} \mathrm{Cl}$ solutions to which 2 percent of material was added]

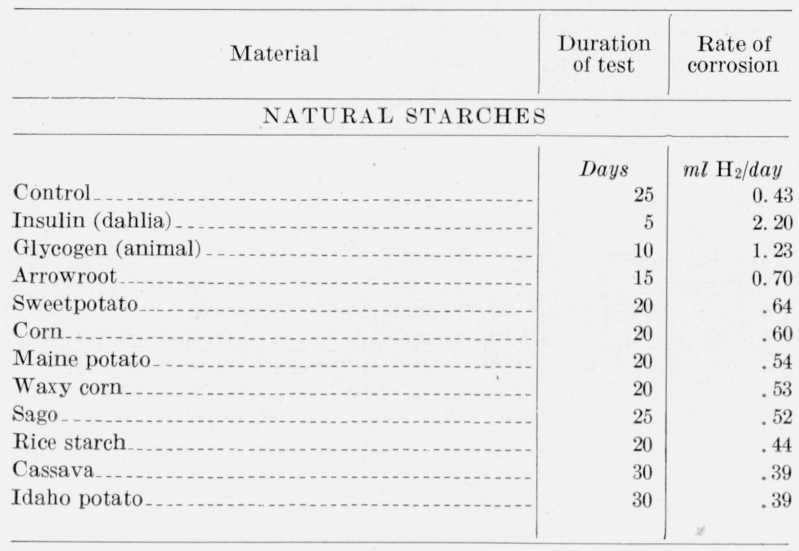

NATURAL FLOURS

\begin{tabular}{l|r|r}
\hline Potato & 30 & 0.40 \\
Soybean & 80 & .14 \\
Rice & 100 & .12 \\
Buckwheat & 90 & .086 \\
Wheat & 100 & .085 \\
Rye & 100 & .081 \\
Whole wheat & 100 & .080
\end{tabular}

MODIFIED STARCHES

\begin{tabular}{lr|r}
\hline Control & 25 & 0.43 \\
Dextrose & 10 & 1.27 \\
Corn amylose 1 & 1 & 1.10 \\
Waxy corn amylopectin & 10 & 0.91 \\
Corn amylopectin & 20 & .60 \\
H-20 cornstarch 2 & 20 & .60 \\
4601 cornstarch 3 & 25 & .48 \\
3006 cornstarch 3 & 30 & .48 \\
Defatted cornstarch & 40 & .44 \\
Zein & 45 & .31 \\
Glycerite of starch & 50 & .15 \\
HSI cornstarch ${ }^{4}$ &
\end{tabular}

MODIFIED FLOURS

\begin{tabular}{lr|r}
\hline Glutenin & 30 & 0.36 \\
$4^{\circ}$ gliadin & 30 & .27 \\
Mesonin I & 50 & .14 \\
Gum gluten & 100 & .094 \\
Gliadin & 100 & .087 \\
Wheat fiour & 100 & .085 \\
Mesonin II & 60 & .063 \\
\hline
\end{tabular}

${ }_{1}^{1}$ To keep amylose in a soluble form, it is kept moist with $n$-butanol. The high value for amylose may be caused by the presence of $n$-butanol, which may have a corrosive effect.

2 Supplied by the National Starch $\mathrm{Co}_{0}$

${ }^{3}$ Supplied by R. W. Kerr, Corn Products Refining Co., Argo, Ill.

${ }_{4}^{4}$ Prepared by H. S. Isbell, National Bureau of Standards.
TABLE 7. Results obtained with colloidal materials at $25^{\circ} \mathrm{C}$-Continued

MISCELLANEOUS MATERIALS

\begin{tabular}{|c|c|c|}
\hline Material & $\begin{array}{l}\text { Duration } \\
\text { of test }\end{array}$ & $\begin{array}{c}\text { Rate of } \\
\text { corrosion }\end{array}$ \\
\hline Ammonium alginate & Days $_{1}$ & $\begin{array}{r}m l \mathrm{H}_{2} / d a y \\
11.3\end{array}$ \\
\hline Carpenter's glue & 5 & 3. 2 \\
\hline Hydroxyethyl cellulose_. & 1 & 2.5 \\
\hline Carboxymethyl cellulose ... & 20 & 0.57 \\
\hline Casein & 40 & .24 \\
\hline Agar agar & 40 & .21 \\
\hline Yellow corn meal ... & 20 & .17 \\
\hline Hemoglobin & 70 & .16 \\
\hline Amidex ............ & 80 & .15 \\
\hline White corn meal _. & 100 & .11 \\
\hline Gelatin & 100 & .11 \\
\hline Powdered acacia & 100 & .11 \\
\hline
\end{tabular}

The flours, with the exception of potato flour, which is low in protein content, all have inhibiting properties for the corrosion of zinc. It is evident from the data that the effective ingredient in flour is gluten, the protein-containing material. Gluten consists of glutenin, and gliadin and mesonin in different states of aggregation. Results obtained with these materials obtained from wheat flour by the combined methods of Stockelbach and Bailey [7] and Haugaard and Johnson [8] showed that with the exception of glutenin all were good inhibitors of the corrosion of zinc. When these materials are incorporated in dry cells they increase somewhat the capacity of dry cells at $21^{\circ} \mathrm{C}$. as shown by the data of table 8 . Current maintenance is defined as the ratio of the flash (or short-circuit) current after an interval of storage to the initial flash current. Many commercial cells give better current maintenance than the experimental controls given here. However, cells with and without proteins (experimental controls) were made under the same procedure, and comparisons should be made with the experimental controls and not with commercial cells. On hydrolysis the flour proteins give amino acids. Therefore, studies were made of the inhibiting properties of several amino acids, with the results given in table 9 . The amino acids have no protective value; in fact most of them accelerate the corrosion of zinc.

Other colloidal materials, including gelatin, agar, acacia, casein, and hemoglobin likewise have inhibiting action. Carboxymethyl cellulose, hydroxymethyl cellulose, and ammonium alginate, which have been tried in the dry cell as substitutes 
for starch and flour, have no inhibiting properties. Amidex, a degradation product of starch, has some inhibiting properties.

TABLE 8. Effect of protein films on the current maintenance 1 of D-size dry cells at $21^{\circ} \mathrm{C}$

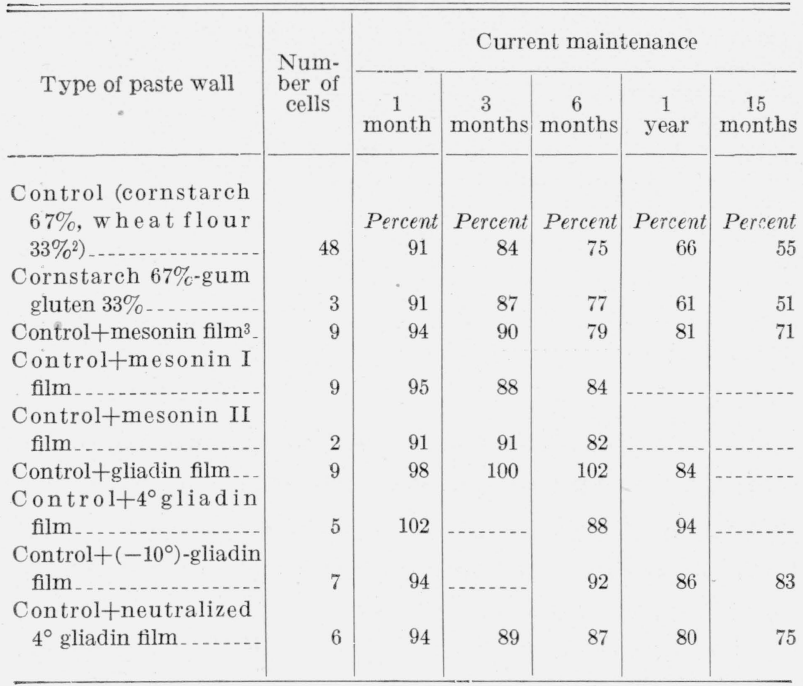

1 Current maintenance is the ratio of the flash (or short-circuit) current after storage to the initial flash current.

2 Many commercial cells give better current maintenance than these experimental controls, but comparisons must be made with the latter.

3 All films covered the zinc can.

TABLE 9. Effect of amino acids on the corrosion of zinc electrodes at $25^{\circ} \mathrm{C}$

\begin{tabular}{|c|c|c|}
\hline Acid & $\begin{array}{l}\text { Duration } \\
\text { of test }\end{array}$ & Rate \\
\hline & Days & $m l \mathrm{H}_{2} / \mathrm{day}$ \\
\hline Control ............. & 25 & 0.43 \\
\hline Leucine...... & 5 & 2. 32 \\
\hline Aspartic acid ........ & 5 & 2. 06 \\
\hline Glutamic acid ........ & 5 & 1.84 \\
\hline Arginine............ & 10 & 0.92 \\
\hline Tryptophane............ & 10 & .91 \\
\hline Control $\ldots$ & 25 & .43 \\
\hline Serine & 10 & .86 \\
\hline Phenyl alanine & 20 & .75 \\
\hline Histidine. $\mathrm{HCl}$ & 10 & .50 \\
\hline Valine & 40 & .33 \\
\hline Alanine & 40 & .31 \\
\hline
\end{tabular}

\section{Zinc-Corrosion Experiments by the Loss-in-Weight Method}

As the conditions in the gas tubes are not entirely similar to conditions in the dry cell, and as solutions of higher concentrations of starch and flour could not be conveniently and satisfactorily tested in these tubes, a few corrosion experiments by a loss-in-weight method were undertaken.
TABLE 10. Loss in weight of D-size zinc cans containing $30 \mathrm{ml}$ of paste after storage at $54^{\circ} \mathrm{C}$

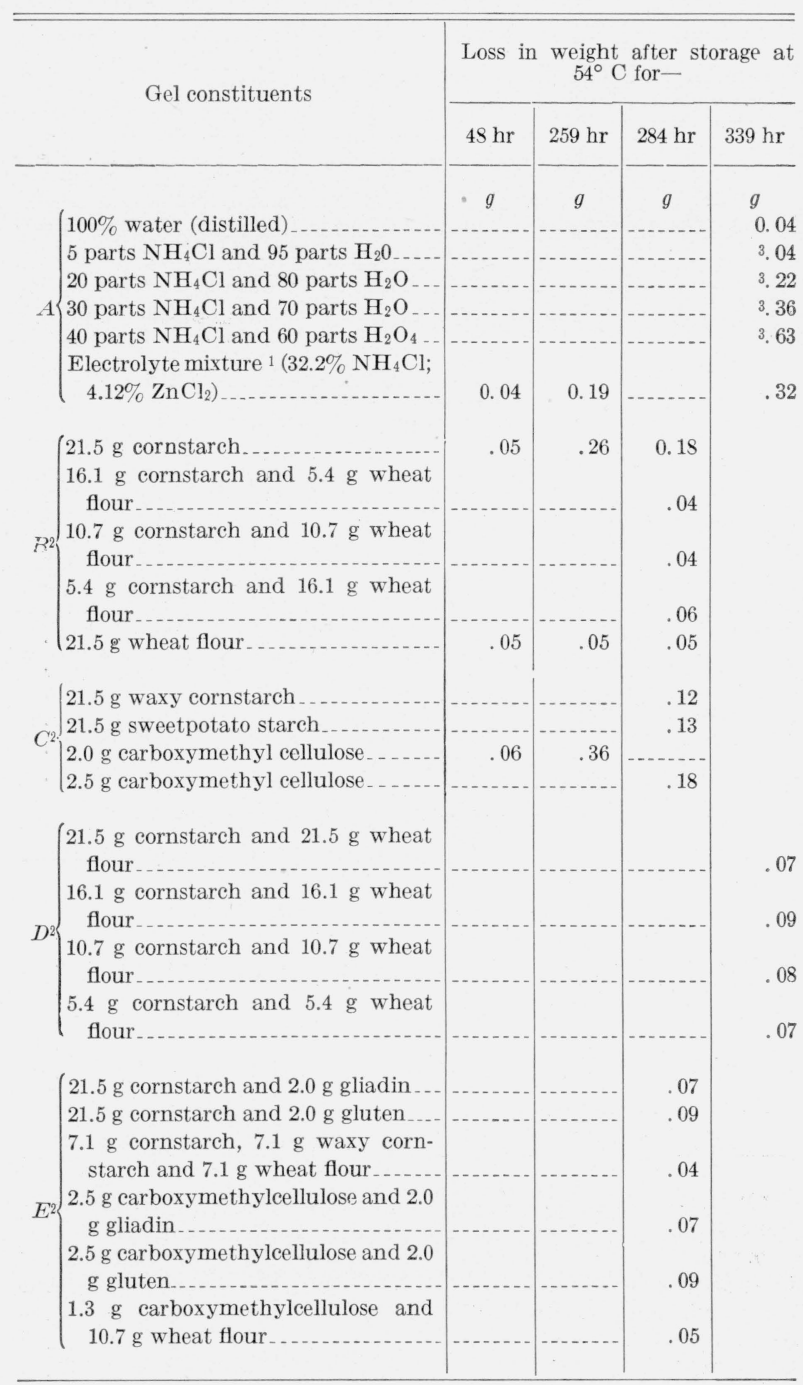

1 The electrolyte mixture consisted of $46.1 \mathrm{~g}$ of $\mathrm{NH}_{4} \mathrm{Cl}$ and $12.3 \mathrm{~g}$ of $\mathrm{ZnCl}_{2}$ in $100 \mathrm{ml}$. of $\mathrm{H}_{2} \mathrm{O}$.

2 Added to $93 \mathrm{ml}$ of the electroylte mixture.

3334 hours.

${ }^{4}$ Saturated; crystals of $\mathrm{NH}_{4} \mathrm{Cl}$ on can.

A paste of electrolyte and cereal was poured into a D-size zinc can of known weight, and mineral oil was poured over the paste to prevent evaporation. After storage in an oven at $54^{\circ} \mathrm{C}$, the can was thoroughly cleaned of paste and weighed. Results obtained by this method, given in table 10 (A) show "the corrosive effect of the electrolyte concentration. Concentrated solutions of ammonium chloride are more corrosive than dilute, and the addition of zinc chloride decreases the rate of corrosion, as expected. Results of table 
10 also show that a flour paste has more inhibiting properties than a starch paste (B) or a carboxymethyl cellulose paste $(\mathrm{C})$, in conformity with the results obtained with the gas experiments. The amount of flour in the paste (D) that is necessary to inhibit corrosion need not be very large. The results (E) also show that a starch or a carboxymethyl cellulose paste can be made less corrosive by the addition of small amounts of either flour, gum gluten, or gliadin.

\section{Conclusions}

The results of this investigation have shown that the corrosion of zinc in saturated solutions of ammonium chloride may be curtailed by organic compounds containing the carbonyl group, by heterocyclic nitrogen-containing compounds with one or more rings attached to the heterocyclic group, by certain commercial products, and by colloidal materials. Of these the heterocyclic compounds were the best. For example, quinaldine, quinoline, furfural, $p$-dipyridyl, $\beta$-naphthoquinaldine, and $\beta$-naphthoquinoline were better inhibitors of the corrosion of zine in dry-cell electrolytes at $54^{\circ} \mathrm{C}$ than mercury (amalgamation) or chromate films.

Of those materials found to retard the corrosion of zinc, only the colloidal materials could be incorporated in dry cells. Most of the noncolloidal materials either reacted with the paste wall of the dry cell or formed an insoluble film, like a varnish, over the entire surface of the zinc anode, and contributed to the internal resistance and reduced the electrical output of the dry cell.
It was found that the paste wall of the dry cell has inhibiting properties, provided it contains a colloidal protein like wheat flour. The active inhibiting agent of the flour was found to be gluten. The constituents of gluten, namely, glutenin, and gliadin and mesonin in different states of polymerization were isolated. Of these, gliadin and mesonin were found to be effective in retarding the corrosion of zinc in dry-cell electrolytes. When these materials are incorporated in dry cells, they increase somewhat the capacity of the cells.

The authors are indebted to Alfred Douty and George S. Gardner of the American Chemical Paint Co., to C. F. Prutton of the Lubrizol Corporation, and to D. G. Miller, of the Reilly Tar \& Chemical Corporation, for their cooperation during the course of this investigation and for furnishing many of the commercial inhibitors.

\section{References}

[1] W. J. Hamer, J. P. Schrodt, and G. W. Vinal, Trans. Electrochem. Soc., Preprint 90-30, 367 (1946).

[2] L. C. Copeland and F. S. Griffith, Trans. Electrochem. Soc. 89, 495 (1946).

[3] H. F. MeMurdie, D. N. Craig, and G. W. Vinal, Trans, Electrochem. Soc. Preprint 90-31, 383 (1946).

[4] C. A. Mann, Trans. Electrochem. Soc. 69, 115 (1936).

[5] W. J. Hamer. Unpublished.

[6] J. H. Bartram and P. J. C. Kent, Metallurgia 33, 179 (1946).

[7] L. S. Stockelback and C. H. Bailey, Cereal Chem. 15, 801 (1938).

[8] G. Haugaard and A. H. Johnson, J. Biol. Chem. 93, 677 (1931).

Washington, October 1, 1947. 